\title{
Observation of the side chain $O$-methylation of glutamic acid or aspartic acid containing model peptides by electrospray ionization-mass spectrometry
}

\author{
A. Emin Atik*, Melda Z. Guray, Talat Yalcin* \\ Department of Chemistry, Faculty of Science, Izmir Institute of Technology, 35430, Urla, Izmir, Turkey
}

\section{A R T I C L E I N F O}

\section{Article history:}

Received 30 March 2016

Received in revised form 2 September 2016

Accepted 31 December 2016

Available online 2 January 2017

\section{Keywords:}

O-methylation

Glutamic acid

Aspartic acid

ESI-MS

\begin{abstract}
A B S T R A C T
$O$-methylation of the side chains of glutamic acid (E) and aspartic acid (D) residues is generally observed modification when an acidified methanol/water $\left(\mathrm{MeOH} / \mathrm{dH}_{2} \mathrm{O}\right)$ mixture is used as a solvent system during sample preparation for proteomic research. This chemical modification may result misidentification with endogenous protein methylation; therefore, a special care should be taken during sample handling prior to mass spectrometric analysis. In the current study, we systematically examined the extent of E/D methylation and C-terminus carboxyl group of synthetic model peptides in terms of different incubation temperatures, storage times, and added acid types as well as its percentages. To monitor these effects, C-terminus amidated and free acid forms of synthetic model peptides comprised of E or D residue(s) have been analyzed by electrospray ionization-mass spectrometry (ESI-MS). Additionally, LC-MS/MS experiments were performed to confirm the formation of methylated peptide product. The results showed that the rate of methylation was increased as the temperature increases along with prolong incubation times. Moreover, the extent of methylation was remarkably high when formic acid (FA) used as a protonation agent instead of acetic acid (AA). In addition, it was found that the degree of methylation was significantly decreased by lowering acid percentages in ESI solution. More than one acidic residue containing model peptides have been also used to explore the extent of multiple methylation reaction. Lastly, the ethanol $(\mathrm{EtOH})$ and isopropanol $(\mathrm{PrOH})$ have been substituted separately with $\mathrm{MeOH}$ in sample preparation step to investigate the extent of esterification reaction under the same experimental conditions. However, in the positive perspective of view, this method can be used as a simple, rapid and cheap method for methylation of acidic residues under normal laboratory conditions.
\end{abstract}

(c) 2017 Elsevier B.V. All rights reserved.

\section{Introduction}

In the past two decades, electrospray ionization-mass spectrometry (ESI-MS) has been recognized as a promising method for the analysis of biological macromolecules [1,2]. In particular, identification and characterization of posttranslational modifications (PTMs) of proteins (phosphorylation, methylation, glycosylation, acetyla-

Abbreviations: AA, acetic acid; $\mathrm{CBB}$, commassie brilliant blue; CID, collisioninduced dissociation; D, aspartic acid; E, glutamic acid; ESI-MS, electrospray ionization-mass spectrometry; EtOH, ethanol; FA, formic acid; $i \mathrm{PrOH}$, isopropanol; LC-MS/MS, liquid chromatography-tandem mass spectrometry; MALDI, matrixassisted laser desorption ionization; $\mathrm{MeOH}$, methanol; MS/MS, tandem mass spectrometry; pE, pyroglutamic acid; PTM, posttranslational modification.

* Corresponding authors.

E-mail addresses: ahmetatik@iyte.edu.tr (A.E. Atik), talatyalcin@iyte.edu.tr (T. Yalcin). tion, etc.) can be achieved via tandem mass spectrometry (MS/MS) experiments [3,4]. Among these modifications, protein methylation is one of the most prominent PTM found in eukaryotic cells. It plays vital roles in regulation of histones, DNA repair, RNA processing, and signal transduction [5-9]. Previous reports showed that methylation is generally observed on lysine $(K)$ and arginine $(R)$ residues $[8,10]$. However, recent works have revealed that glutamic acid (E), aspartic acid $(D)$, glutamine $(\mathrm{Q})$, asparagine $(\mathrm{N})$, cysteine $(\mathrm{C})$, and histidine $(\mathrm{H})$ residues may also undergo methylation $[8,11,12]$. A very recent report by Wang et al. [13] demonstrated the preference of protein methylation follows $\mathrm{K} » \mathrm{R}>\mathrm{D}>\mathrm{N} \sim \mathrm{Q} \sim \mathrm{H}>\mathrm{E}>\mathrm{C}$ trend in Saccharomyces cerevisiae.

The artificial methylation on $\mathrm{E}$ residue as well as at the Cterminus of peptide has been observed for the first time by Haebel et al. [14] during staining procedure of polyacrylamide gels. The staining solution buffer consists of trichloroacetic acid (TCA) and methanol $(\mathrm{MeOH})$ and it was shown that $\gamma$-carboxyl group of E con- 
verted to its corresponding methyl ester form via acid-catalyzed esterification reaction. Additionally, the authors highlighted that the rate of $\mathrm{D}$ methylation was too slow compared to the E methylation. They also provide an evidence for ethylation of $\mathrm{E}$ when ethanol (EtOH) was used instead of $\mathrm{MeOH}$ as a solvent [14]. On the other hand, Sprung et al. [12] have reported that the side chains of $\mathrm{E}$ and $\mathrm{D}$ can be methylated when $\mathrm{MeOH}$ was used as a solvent in protein extraction protocols and gel-staining/destaining buffers of proteomic studies. A short communication by Sumpton and Bienvenut [15] has demonstrated that the use of colloidal Commassie brilliant blue (CBB) dissolved in trace amount of phosphoric acid containing $\mathrm{MeOH}$ can induce methylation of side chains of acidic residues (E and $\mathrm{D}$ ) during gel staining procedures. Additionally, it has been shown that MALDI matrix/sample preparation procedures may also cause acidic residues to be methylated [16].

From organic chemistry, it has been well known that the condensation reactions of carboxylic acids with an excess alcohol produce an ester. The reaction mechanism proceeds in the presence of a strong acid, therefore it is also known as an acid-catalyzed esterification (Fischer esterification). Previous studies showed that various carboxylic acids were converted to their corresponding methyl ester derivative under methanol/trimethylchlorosilane solvent system [17-19]. Similarly, E and D residues can be easily converted to their methyl ester form when $\mathrm{MeOH}$ has been used as a solvent in acidic media [14,16,20].

In ESI-MS experiments, a mixture with an equal proportion of polar/volatile organic solvent (e.g. $\mathrm{MeOH}$, acetonitrile, or isopropanol) and ultrapure water has been used especially via direct infusions. The organic solvents generally added to the liquid mixture to decrease the surface tension which facilitates formation of gas-phase ions through ESI process. Among these solvents, $\mathrm{MeOH}$ is one of the most extensively used organic solvent for solubilising of proteins and peptides prior to mass spectrometric analysis. It is preferred due to its high polarity, volatility, and compatibility. Moreover, in the positive mode MS analysis, the analyte solution is generally acidified with formic acid (FA) or acetic acid (AA) with a range of $0.1-1 \%$ to promote ionization.

In our previous studies on the fragmentation reactions of $E / D$ containing model peptides $[21,22]$, we detected $[\mathrm{M}+\mathrm{H}+14]^{+}$ions in the full scan mass spectra (MS). Further MS/MS experiments have revealed that the side chains of E/D residue were methylated. The formation of unexpected methylated derivative of peptide can be explained by long term storage of ESI solution in an acidified methanolic solution. Therefore, in the current study, we comprehensively investigate the extent of side chain methylation of E/D residues and/or C-terminus carboxyl group of peptide chain in terms of different incubation temperatures, storage times, added acid types and its percentages. Additionally, two adjacent E or D residue containing model peptides have been also used in order to probe the extent of multiple methylation reaction. Lastly, the effects of organic solvent on the esterification reaction have been also studied.

\section{Experimental}

\subsection{Chemicals and sample preparations}

The model peptides (either C-terminus free acid or amide forms) were purchased from GL Biochem Ltd. (Shanghai, China) as a lyophilized powder (purity >90\%) and used without any further purification. HPLC-grade methanol $(\mathrm{MeOH})$, and ethanol (EtOH) were provided by Sigma Aldrich. The analytical grade formic acid (FA, purity of $98-100 \%$ ) and trifluoroacetic acid (TFA) were purchased from Merck (Darmstad, Germany); acetic acid (100\%, puriss) was from Riedel-de Haën; isopropyl alcohol (iPrOH, Biochemica) was from Applichem (Darmstad, Germany). Throughout the study, ultra-pure water (18.2 M $\Omega$ ) was used (Arium $611 \mathrm{UV}$, Sartorius AG, Goettingen, Germany). The solid peptide samples were dissolved in a 50:50 (v/v) mixture of organic solvent (methanol, ethanol, or isopropanol) and ultra-pure water just before to use.

\subsection{Mass spectrometry}

Mass spectrometry experiments were conducted on a LTQ XL linear ion-trap mass spectrometer (Thermo Finnigan, San Jose, CA, USA) equipped with an electrospray ionization (ESI) source. The system was operated in the positive mode and the spray voltage was set to $+5.0 \mathrm{kV}$ and the heated capillary temperature at $300^{\circ} \mathrm{C}$. All ion optics was optimized in order to get maximum ion intensity with an auto-tune function of the ion-trap instrument. A $100 \mathrm{pmol} \mu \mathrm{L}^{-1}$ peptide solutions were introduced into the ion source with an incorporated syringe pump at a flow rate of $5 \mu \mathrm{L} / \mathrm{min}$. The default peptide working solutions were prepared in $\mathrm{MeOH} / \mathrm{dH}_{2} \mathrm{O} / \mathrm{HCOOH}(50: 50: 1, \mathrm{v} / \mathrm{v} / \mathrm{v}$ ) containing mixture. Nitrogen was used as a sheath, an auxiliary, and a sweep gas with a flow rate of $10,1,1$ (in arbitrary unit), respectively, where helium was used as a collision gas for CID. Full scan MS spectra were acquired in the $m / z$ range $150-1000$ and at least 500 scans were averaged in profile mode. For the tandem mass spectrometry (MS/MS) experiments, the mass isolation window $(\mathrm{m} / \mathrm{z})$ was set at between 1.0 and 1.4 with an activation time of $30 \mathrm{~ms}$ and an activation (q) of 0.250 . The normalized collision energy was set to $20-26 \%$ for the fragmentation of selected precursor ion via (MS/MS). Data acquisition was performed with Xcalibur (ver. 2.0) software data system and all data were futher processed using Igor Pro Software package (WaveMetrics, Lake Oswego, OR).

\subsection{High-performance liquid chromatography}

High-performance liquid chromatography (HPLC) experiments were performed on a Dionex Ultimate ${ }^{\mathrm{TM}} 3000$ Nano/Cap system (Dionex, Camberley, UK) using a Kromasil $C_{18}$ column $(10 \mathrm{~cm}$ length $\times 2.1 \mathrm{~mm}$ i.d., $3.5-\mu \mathrm{m}$ particle size, $100 \mathrm{~A}^{\circ}$ pore diameter). The column temperature was maintained at $25^{\circ} \mathrm{C}$. Mobile phases $A$ and $B$ were composed of $0.1 \%$ trifluoroacetic acid (TFA) in water and acetonitrile, respectively. Peptides were eluted with a thirty minute gradient program: $15 \%$ B for $0 \mathrm{~min}$; followed by a gradient of $15-40 \% \mathrm{~B}$ in $25 \mathrm{~min}$ and $80 \% \mathrm{~B}$ for $25.01-30 \mathrm{~min}$. The UV detection wavelength was set to $220 \mathrm{~nm}$. The flow rate was $200 \mu \mathrm{L} / \mathrm{min}$ and the injection volume was $5 \mu \mathrm{L}$ which contains approximately $5 \mu \mathrm{g}$ of peptide sample. Eluted peptides were then splitted with $1 / 20$ ratio form the exit of the detector and were directed into the mass spectrometer equipped with an ESI source. The chromatograms were monitored via on-line recording of the full mass scans within the 150-600 mass range.

\section{Results and discussion}

\subsection{Effects of different incubation temperatures and storage times on the methylation reaction}

In the first part of this study, EGGFL- $\mathrm{NH}_{2}$ and DGGFL-NH $\mathrm{N}_{2}$ synthetic model pentapeptides were primarily used to investigate the effects of incubation temperatures and storage times for the extent of methylation reaction. As noted, these peptides have an amide group rather than free carboxylic acid at their C-terminus; therefore, only possible methylation site is on the side chain of $E$ or $D$ residue. Other amino acid residues within the sequence $(G, F$, and L) do not bear carboxylic acid group on their side chains; therefore they are inert to methylation. For each peptide sample, five working ESI solutions with a concentration of $100 \mathrm{pmol}_{\mu \mathrm{L}^{-1}}$ were 

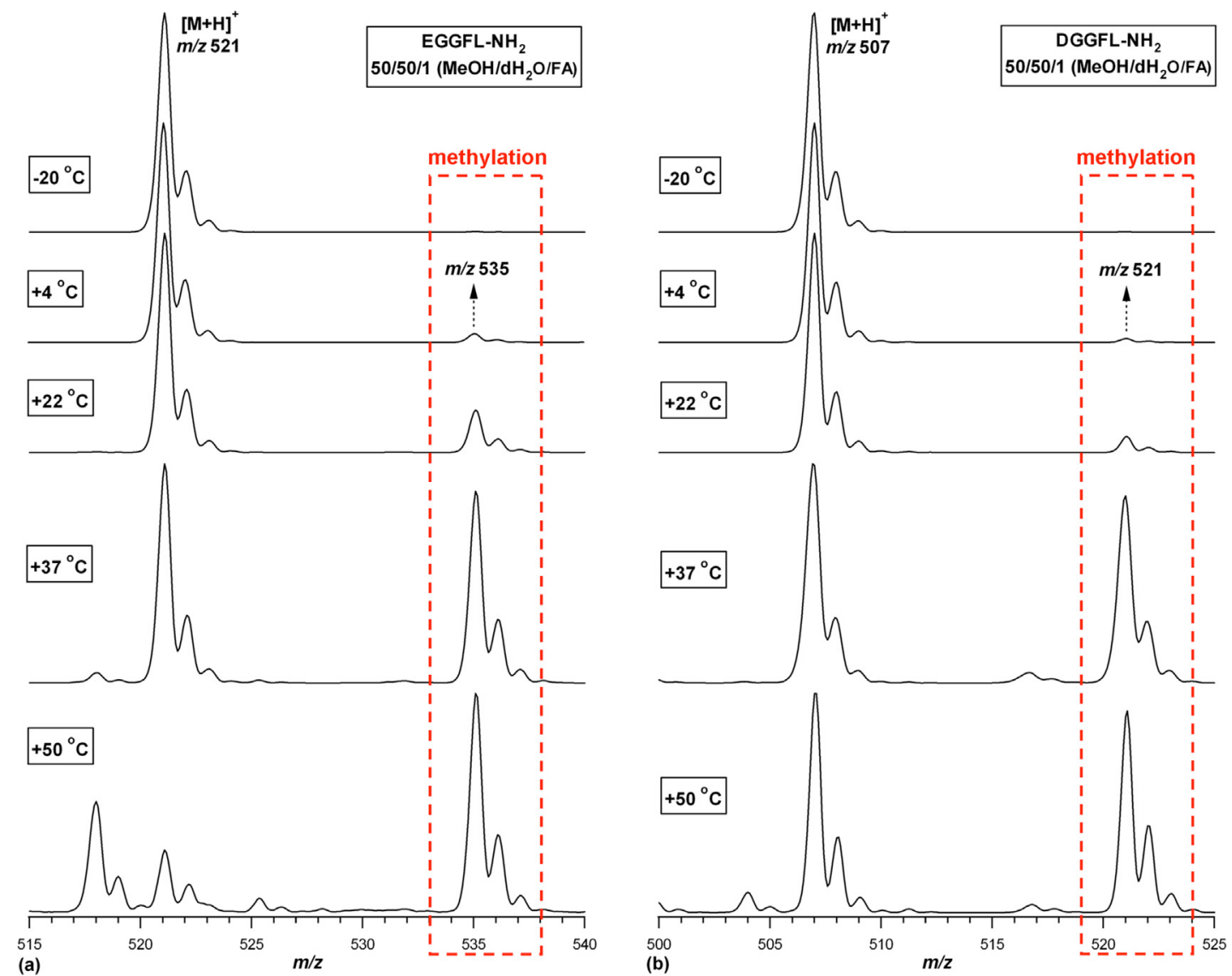

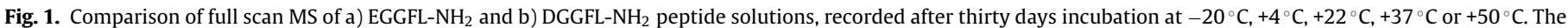
ESI solutions were prepared in 50:50:1 (v/v/v) $\mathrm{MeOH}_{\mathrm{d}} \mathrm{dH}_{2} \mathrm{O} / \mathrm{FA}$.

freshly prepared in $\mathrm{MeOH} / \mathrm{dH}_{2} \mathrm{O} / \mathrm{FA}$ (50:50:1, v/v/v) mixture. The prepared peptide samples were immediately infused into the mass spectrometer and full scan MS were acquired in the mass range of $m / z 150-600$. Then, each of these solutions were allowed to incubate at different temperatures; such as, $-20^{\circ} \mathrm{C},+4^{\circ} \mathrm{C},+22^{\circ} \mathrm{C},+37^{\circ} \mathrm{C}$, or $+50^{\circ} \mathrm{C}$. For each incubated solutions, full scan MS were recorded over time periods of 1, 3, 7, 14 and 30 days. The obtained full scans MS for EGGFL- $\mathrm{NH}_{2}$ and DGGFL- $\mathrm{NH}_{2}$ peptides over different temperatures and time periods are given in Fig. S1-S4. For simplicity, only comparison of full scan MS recorded at five different temperatures after thirty-day incubation is shown in Fig. 1.

As illustrated in Fig. 1a, the protonated molecular ion, $[\mathrm{M}+\mathrm{H}]^{+}$, of EGGFL- $\mathrm{NH}_{2}$ is $m / z$ 521. Interestingly, one can note that $m / z 535$ ion was appeared in the full scan MS of solutions which were incubated at $+4{ }^{\circ} \mathrm{C},+22^{\circ} \mathrm{C},+37^{\circ} \mathrm{C}$, and $+50^{\circ} \mathrm{C}$ for thirty-days (labeled with red-dotted rectangular box). This peak is separated by a $+14 \mathrm{Da}$ from $[\mathrm{M}+\mathrm{H}]^{+}$ion and this mass shift is attributed to the methylation. In line with the previous studies $[12,20]$, it was assumed that the side chain of $\mathrm{E}$ has been methylated during storage of its ESI solution in $\mathrm{MeOH} / \mathrm{dH}_{2} \mathrm{O} / \mathrm{FA}(50: 50: 1, \mathrm{v} / \mathrm{v} / \mathrm{v}$ ). As a result, a methylated peptide product, $\mathrm{E}_{\mathrm{OMe}} \mathrm{GGFL}-\mathrm{NH}_{2}$, was formed in solution phase. To confirm this, the $\mathrm{m} / \mathrm{z} 535$ ion was isolated and allowed to dissociate under low-energy CID which then compared with the MS/MS spectrum of $[\mathrm{M}+\mathrm{H}]^{+}$ion of commercial side-chain methylated pentapeptide, $\mathrm{E}_{\mathrm{OMe}} \mathrm{GGFL}-\mathrm{NH}_{2}$, (shown in Fig. 2). The fragmentation behavior of $m / z 535$ ion and $[\mathrm{M}+\mathrm{H}]^{+}$ion of commercial $\mathrm{E}_{\mathrm{OMe}} \mathrm{GGFL}-\mathrm{NH}_{2}$ pentapeptide are virtually identical by having the same fragment ions along with the same relative intensities. The one-to-one similarity of these two mass spectra provided a strong evidence for side chain methylation of E during storage of its ESI
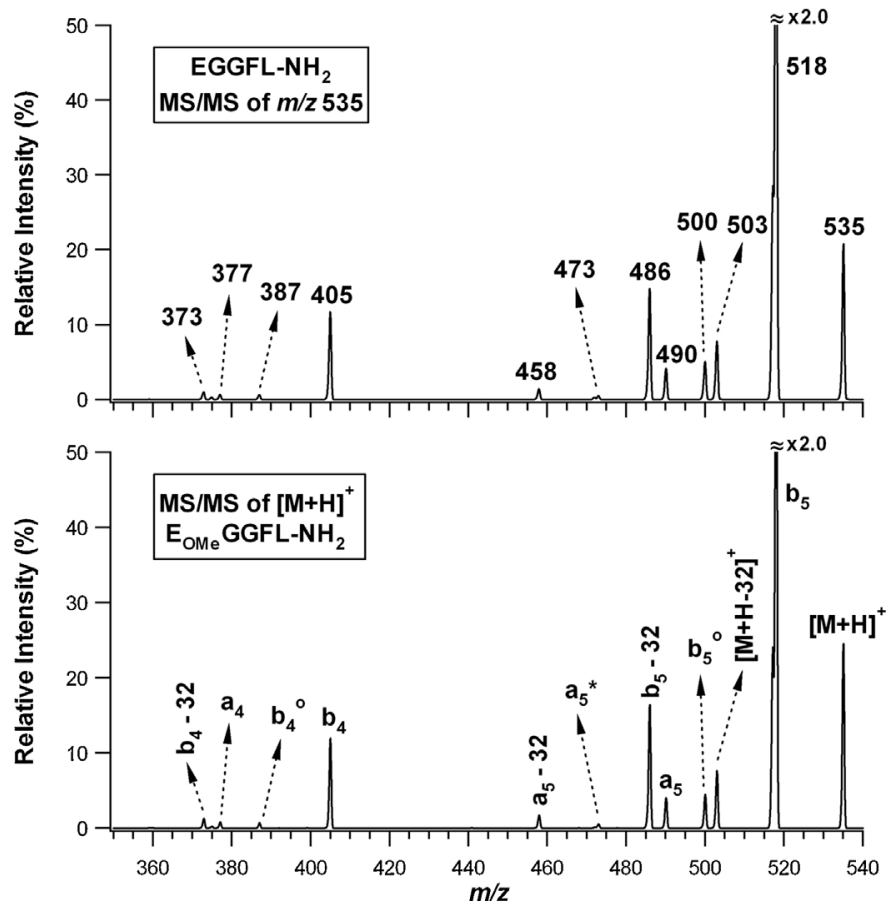

Fig. 2. Comparison of MS/MS spectrum of $m / z 535$ ion observed in the full scan MS of protonated EGGFL-NH$H_{2}$ and MS/MS spectrum of $[\mathrm{M}+\mathrm{H}]^{+}$ion of protonated $\mathrm{E}_{\mathrm{OMe}} \mathrm{GGFL}-\mathrm{NH}_{2}$. 
solution in $\mathrm{MeOH} / \mathrm{dH}_{2} \mathrm{O} / \mathrm{FA}(50: 50: 1, \mathrm{v} / \mathrm{v} / \mathrm{v})$. A facile loss of $32 \mathrm{Da}$ (mass of methanol) from $[\mathrm{M}+\mathrm{H}]^{+}, b$, and/or $a$ ions unambiguously supports the formation of methylated peptide product. In Fig. 2, a water loss from $b_{5}$ ion and an ammonia loss from $a_{5}$ ion are denoted as $b_{5}{ }^{\circ}$ and $a_{5}{ }^{*}$, respectively.

Similarly, the $m / z 521$ ion was detected while recording the full scan MS of DGGFL- $\mathrm{NH}_{2}$ at $+4{ }^{\circ} \mathrm{C},+22^{\circ} \mathrm{C},+37^{\circ} \mathrm{C}$, and $+50^{\circ} \mathrm{C}$ after thirty-day incubation (see Fig. 1b, red-dotted rectangular box). The $[\mathrm{M}+\mathrm{H}]^{+}$ion of peptide is $\mathrm{m} / \mathrm{z} 507$ and once again there is $+14 \mathrm{Da}$ mass shift which may correspond to the side chain methylation of $D$ residue. Detailed MS/MS experiments showed that $\mathrm{MeOH} / \mathrm{dH}_{2} \mathrm{O} / \mathrm{FA}$ (50:50:1, v/v/v) solution composition giving rise to formation of $\mathrm{D}_{\mathrm{OMe}} \mathrm{GGFL}-\mathrm{NH}_{2}$ peptide product in solution.

As shown in Fig. 1, neither EGGFL- $\mathrm{NH}_{2}$ nor DGGFL- $\mathrm{NH}_{2}$ undergoes methylation when their solutions were stored at $-20^{\circ} \mathrm{C}$ for thirty days. Additionally, no methylated peptide products were detected even after six-month incubation at $-20^{\circ} \mathrm{C}$ (spectra not shown). It is obvious that an ESI solution remain stable under this condition. On the contrary, it is apparent that the relative intensities of methylated peptide products have become more significant as the temperature increases. It is worth noting here that the rate of $E$ methylation was rapid in comparison to $D$ methylation for all tested temperatures, except $+37^{\circ} \mathrm{C}$, at least when C-terminus amidated model pentapeptides were used. Previous report by Haebel et al. [14] demonstrated that the rate of methylation was selective for E instead of D residue. Our results differ from Haebel et al. [14] report in terms of $\mathrm{D}$ methylation.

Overall, these results suggested that methylation of E/D residue within the peptide sequence is temperature dependent process and the rate of reaction is increased as the temperature increases. Moreover, as Fig. S1-4 illustrates, the relative intensities of methylated peptide products greatly dominate the mass spectra with increasing incubation time for all tested temperatures.

On the other hand, the conversion of N-terminus $\mathrm{E}$ to pyroglutamic acid (pE) has been reported previously [23-25] through water loss from its $\gamma$-carboxyl group; especially when its acidic solution is incubated at elevated temperatures. Therefore, in the current work, in addition to the formation of methylated prod-

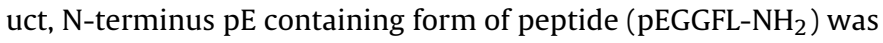
also observed at $m / z 503$ while recording full scan MS of $+37^{\circ} \mathrm{C}$ incubated EGGFL- $\mathrm{NH}_{2}$ solution. Hence, to gain more insight into the formation of $\mathrm{E}_{\mathrm{OMe}} \mathrm{GGFL}-\mathrm{NH}_{2}$ and $\mathrm{pEGGFL}-\mathrm{NH}_{2}$ in solution phase, both freshly prepared and seven-day $+37^{\circ} \mathrm{C}$ incubated of EGGFL- $\mathrm{NH}_{2}$ peptide solutions were injected separately into the high-performance liquid chromatography (HPLC). The comparison of HPLC chromatograms is shown in Fig. 3. Briefly, the retention time for freshly prepared peptide was $7.5 \mathrm{~min}$ (see upper panel). However, for seven-day incubated peptide sample, in addition to the unmodified form (with a retention time of $7.7 \mathrm{~min}$ ), two distinct peaks were also observed at the retention times of 8.5 and $9.5 \mathrm{~min}$ (see lower panel). Each eluted peak was introduced directly into the MS and was identified as pEGGFL- $\mathrm{NH}_{2}$ and $\mathrm{E}_{\mathrm{OMe}} \mathrm{GGFL}-\mathrm{NH}_{2}$, respectively.

Moreover, EGGFL-OH and DGGFL-OH pentapeptides, where the C-terminus of peptides has free acid functionality, were also analyzed. In this case, two possible methylation sites exist: the side chains of $\mathrm{E} / \mathrm{D}$ residue and the $\mathrm{C}$-terminus. The peptide solutions were freshly prepared in $\mathrm{MeOH} / \mathrm{dH}_{2} \mathrm{O} / \mathrm{FA}$ (50:50:1, v/v/v) and their full scan MS were recorded in the mass range of $m / z 150-600$ separately. Then, each peptide solution was incubated for $1,3,7,14$, and 30 days at $+37^{\circ} \mathrm{C}$. For the best representation of the methylation reaction, $+37^{\circ} \mathrm{C}$ was selected as a standard temperature. After each incubation time period, the full scan MS were again recorded for each peptide solution. For simplicity, Fig. 4 displays the comparison of full scan MS of EGGFL-OH and DGGFL-OH peptide solutions incubated at $+37^{\circ} \mathrm{C}$ for thirty days (The obtained full scan MS of

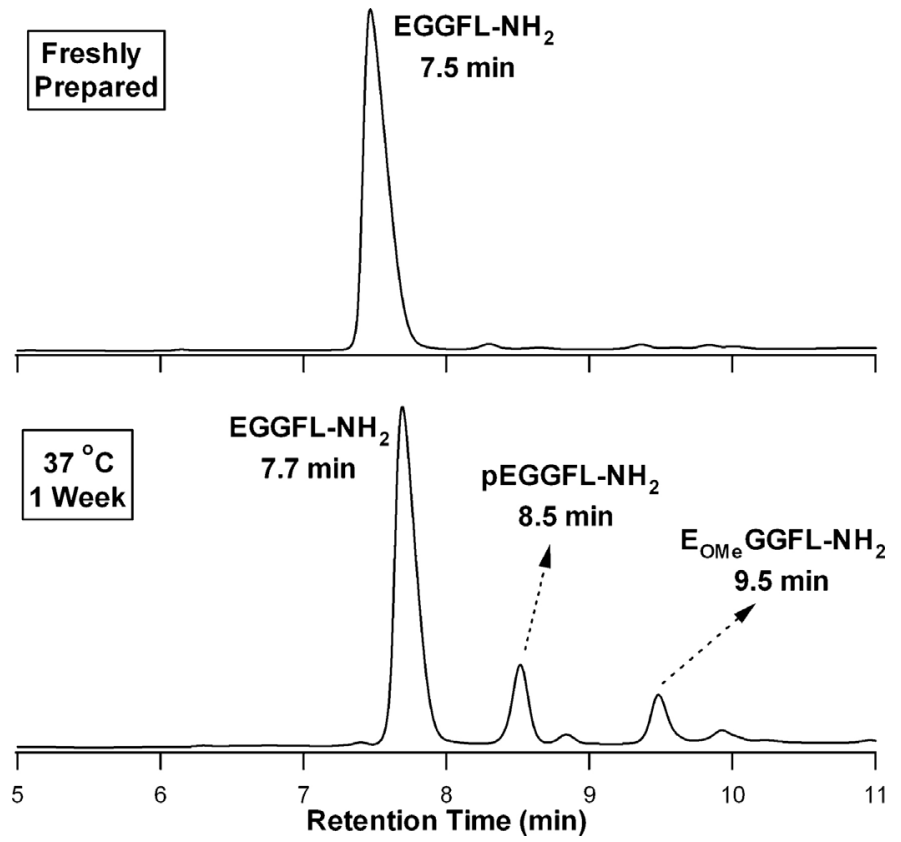

Fig. 3. Comparison of HPLC chromatograms of EGGFL-NH $\mathrm{N}_{2}$ peptide solution for a) freshly prepared and $\mathrm{b}$ ) incubated for one week at $+37^{\circ} \mathrm{C}$.

EGGFL-OH and DGGFL-OH over 1, 3, 7, 14, and 30 days are given in Fig. S5).

Briefly, the $[\mathrm{M}+\mathrm{H}]^{+}$ion of EGGFL-OH is $m / z 522$ and it is confirmed by minor sodium-adduct, $[\mathrm{M}+\mathrm{Na}]^{+}$, at $m / z 544$ (Fig. 4a). It can be noticed that the $m / z 536$ appeared in the full scan MS of EGGFL-OH when its aqueous solution was incubated at $+37^{\circ} \mathrm{C}$ for thirty-days, while it was originally absent for freshly prepared one. This +14 Da mass shift corresponds to the mono-methylation form of peptide, either on the side chain of $\mathrm{E}\left(\mathrm{E}_{\mathrm{OMe}} \mathrm{GGFL}-\mathrm{OH}\right)$ or at the C-terminus of peptide (EGGFL-OMe). To support this observation, the ion at $m / z 536$ was further selected and allowed to fragment via CID. As shown in the upper panel of Fig. 5, the MS/MS spectrum of $m / z 536$ ion consists of several of $b, a$, and $y$-type ions which confirms that two mono-methylated peptide products have been formed at the same time during storage its solution in an acidified $\mathrm{MeOH} / \mathrm{dH}_{2} \mathrm{O}(50: 50, \mathrm{v} / \mathrm{v})$ mixture. Moreover, the ion at $\mathrm{m} / \mathrm{z}$ 550 was also observed in the full scan MS which corresponds to the formation of di-methylated peptide product, $\mathrm{E}_{\mathrm{OMe}} \mathrm{GGFL-OMe}$, in solution. The di-methylated form was further confirmed through assigning its sequence specific ions through its MS/MS spectrum (see lower panel of Fig. 5). In particular, the superscripts “*” and “o" denotes neutral loss of one ammonia ( $-17 \mathrm{Da})$ and one water $(-18 \mathrm{Da})$ molecule from fragment ions. It can be noticed here that the relative intensity of mono-methylated derivative's product ion is higher than di-methylated one.

Likewise, the same behavior was also observed for DGGFL-OH peptide (see Fig. 4b). Briefly, both two mono-methylated peptide products ( $\mathrm{D}_{\mathrm{OMe}} \mathrm{GGFL}-\mathrm{OH}$ and DGGFL-OMe) were observed at $m / z$ 522. Additionally, di-methylated peptide product ( $D_{\text {OMe }} G G F L-$ OMe) was also detected at $m / z$ 536. In here, it can be noticed that methylation rate of $\mathrm{E}$ or D is not significant when C-terminus free acid forms of pentapeptides were used.

Furthermore, to test the methylation with different peptide sequence, AAAXAAA- $\mathrm{NH}_{2}$ and AAAXAAA-OH (X is E or D) synthetic model heptapeptides have been utilized. A $100 \mathrm{pmol}_{\mu \mathrm{L}^{-1}}$ peptide solutions were freshly prepared in $\mathrm{MeOH} / \mathrm{dH}_{2} \mathrm{O} / \mathrm{FA}(50: 50: 1, \mathrm{v} / \mathrm{v} / \mathrm{v}$ ) and their full scan MS were recorded. Again, the peptide solutions were incubated at $+37^{\circ} \mathrm{C}$ for thirty days and then their full scan MS were acquired. The comparison of the recorded spectra for freshly 

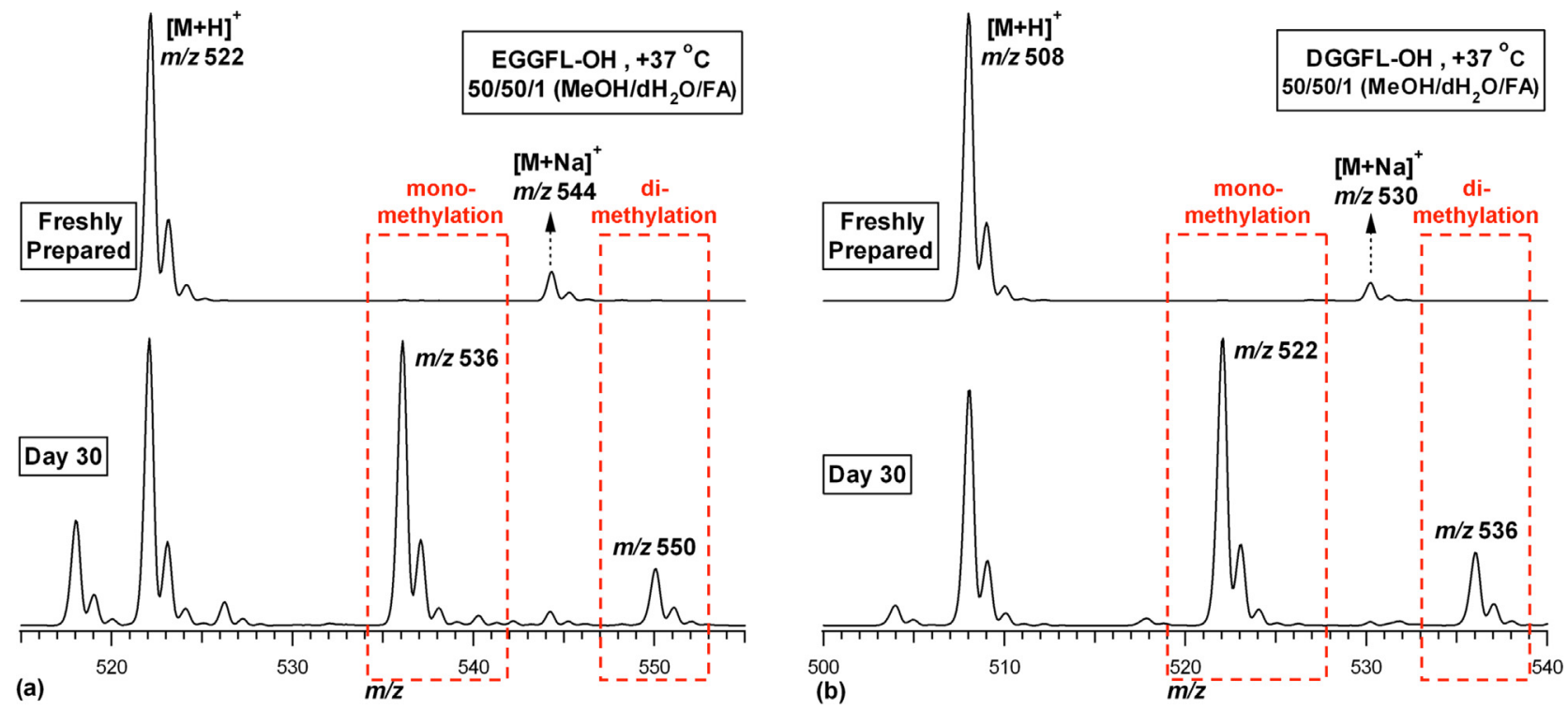

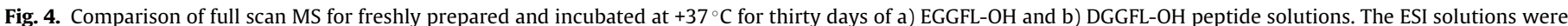
prepared in 50:50:1 (v/v/v) $\mathrm{MeOH} / \mathrm{dH}_{2} \mathrm{O} / \mathrm{FA}$.
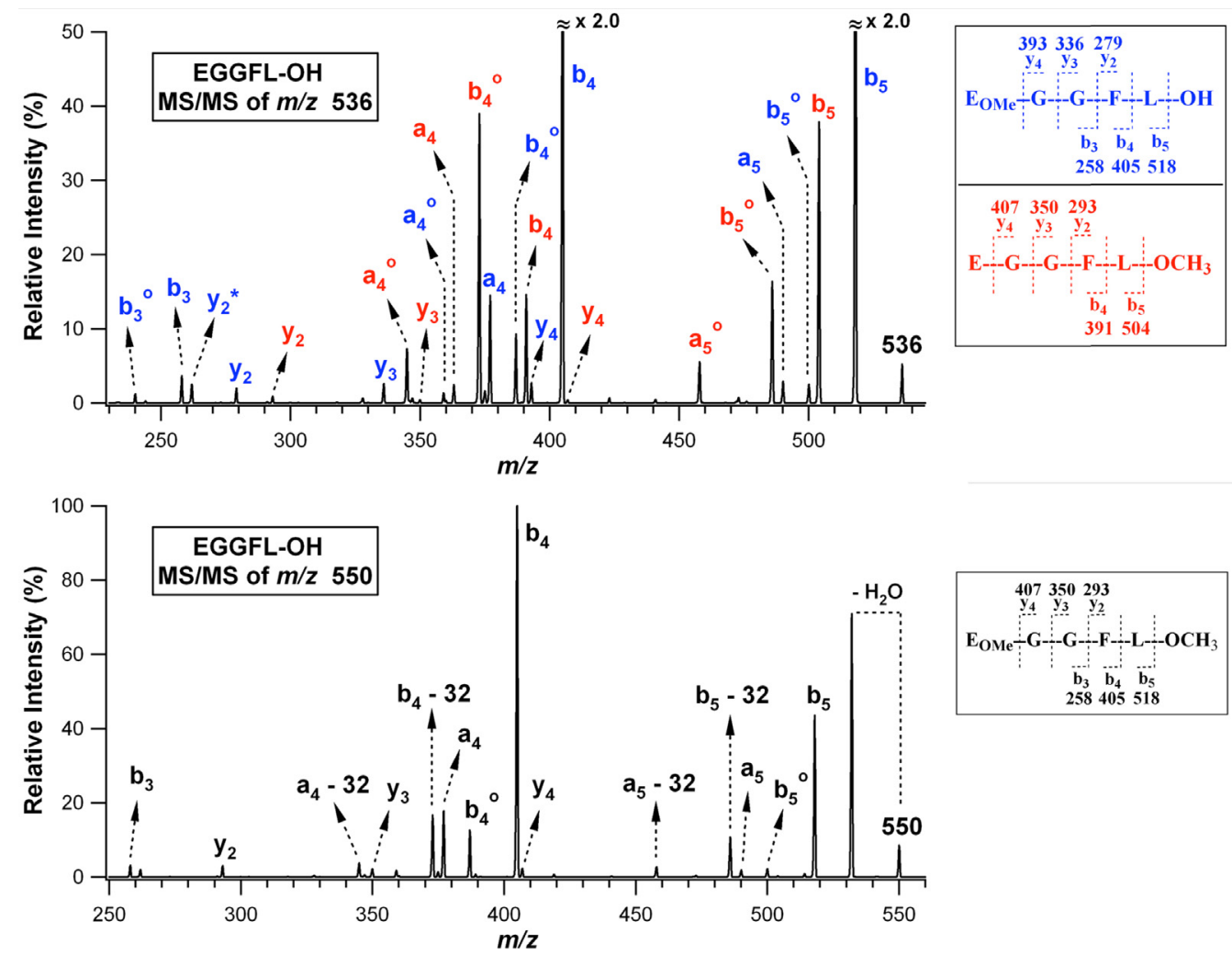

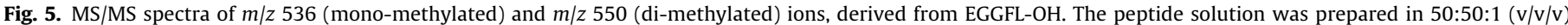
$\mathrm{MeOH} / \mathrm{dH}_{2} \mathrm{O} / \mathrm{FA}$.

prepared and thirty-day incubated peptide samples were shown in Fig. S6 and S7. The $m / z 587$ and 573 ions were appeared in the full scan MS of AAAEAAA- $\mathrm{NH}_{2}$ and AAADAAA- $\mathrm{NH}_{2}$, respectively, which reflects the methylation of acidic residues. It is obvious that the extent of D methylation is low compared to the E methylation and this behavior can be explained by neighboring amino acid effect.
On the other hand, the $m / z 588$ (mono-methylated) and $m / z 602$ (di-methylated) ions were observed for AAAEAAA-OH; while $m / z$ 574 (mono-methylated) and $\mathrm{m} / \mathrm{z} 588$ (di-methylated) ions were detected for AAADAAA-OH. It is clear to see that the relative intensities of mono-methylated peptide product ions are more abundant than the di-methylated peptide products both for $E$ and $D$ residue containing model heptapeptides. 

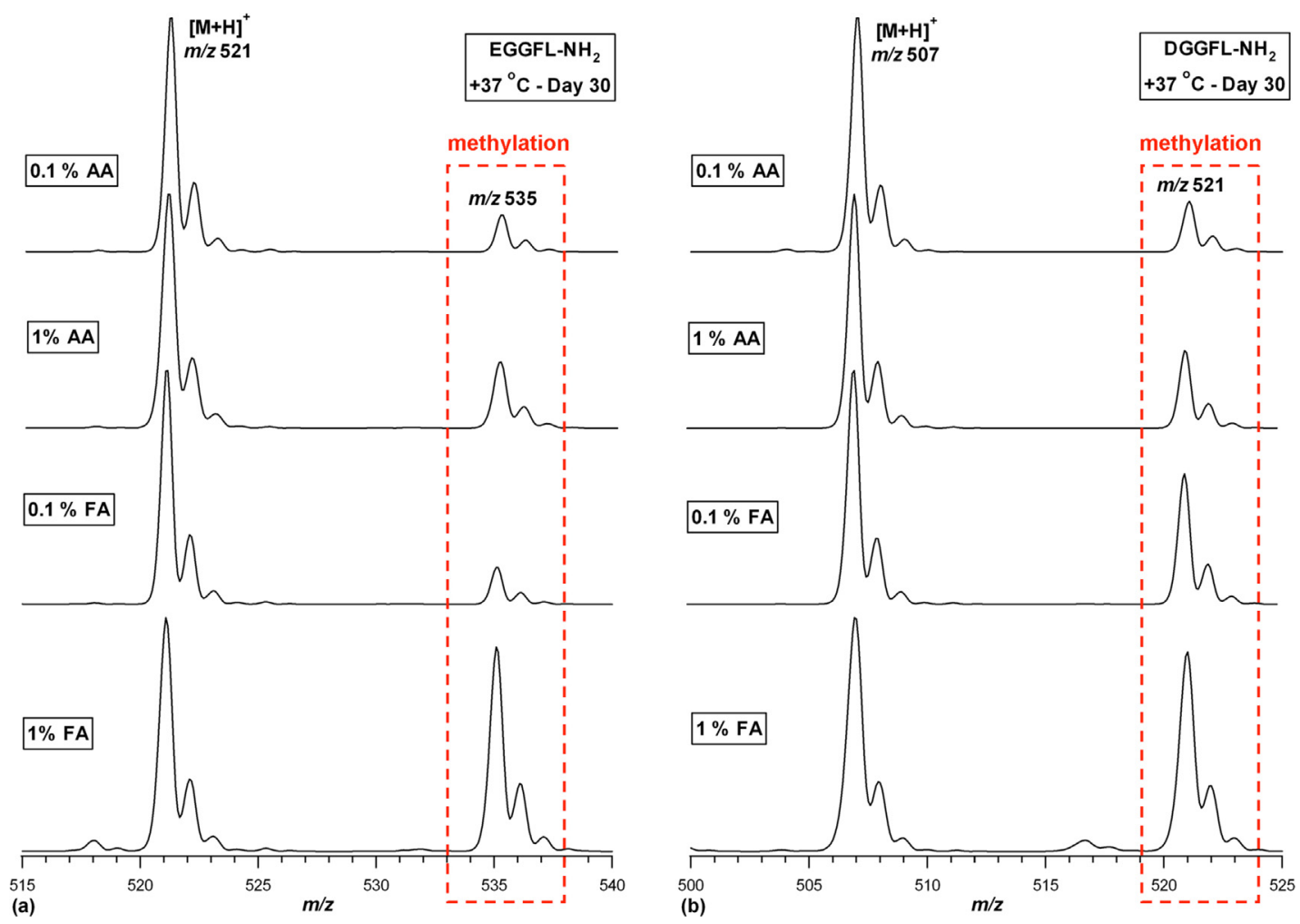

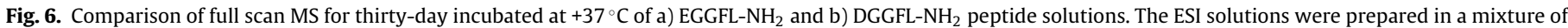
$\mathrm{MeOH} / \mathrm{dH}_{2} \mathrm{O}(50: 50, \mathrm{v} / \mathrm{v})$ containing $0.1 \% \mathrm{AA}, 1 \% \mathrm{AA}, 0.1 \% \mathrm{FA}$ or $1 \% \mathrm{FA}$, respectively.

\subsection{Effects of added acid type and its percentages on the methylation reaction}

In positive-ion mode ESI-MS analysis, a trace amount of acid is usually added to the aqueous solution of analyte to facilitate protonation. Therefore, in the second part of the study, we studied the influence of added acid types as well as their percentages on the methylation of E/D containing peptide. To investigate these effects, formic acid (FA) and acetic acid (AA) with a range of $0.1-1.0 \%$ have been used. At $+25^{\circ} \mathrm{C}$, the tabulated acidities (pKa) of FA and $A A$ are 3.75 and 4.76, respectively, in water [26]. Similar to the previous section, we have used EGGFL-NH $\mathrm{N}_{2}$, DGGFL-NH $\mathrm{N}_{2}$, EGGFL-OH and DGGFL-OH synthetic model pentapeptides and $+37^{\circ} \mathrm{C}$ was selected as a standard temperature in order to best representation of the methylation reaction.

For the purpose of comparison, we prepared peptide solutions in a mixture of $\mathrm{MeOH} / \mathrm{dH}_{2} \mathrm{O}(50: 50, \mathrm{v} / \mathrm{v})$ containing either $1.0 \%$ of FA or AA. The $\mathrm{pH}$ of each solution was measured and their pKa values were calculated as 4.71 and 5.76 , respectively at normal laboratory conditions. The full scan MS were acquired for EGGFL$\mathrm{NH}_{2}$ and DGGFL-NH $\mathrm{N}_{2}$ over time periods of $1,3,7,14$, and 30 days. Fig. 6 shows the comparison of thirty-day incubated EGGFL-NH and DGGFL- $\mathrm{NH}_{2}$ peptide solutions which were prepared either in $\mathrm{MeOH} / \mathrm{dH}_{2} \mathrm{O} / \mathrm{FA}\left(50: 50: 1, \mathrm{v} / \mathrm{v} / \mathrm{v}\right.$ ) or $\mathrm{MeOH} / \mathrm{dH}_{2} \mathrm{O} / \mathrm{AA}$ (50:50:1, $\mathrm{v} / \mathrm{v} / \mathrm{v}$ ) (Other full scan mass spectra are illustrated in Figs. S8 and S9). It is clearly demonstrated that the rate of E/D methylation was low when $1.0 \%$ AA was used instead of $1.0 \%$ FA (see Fig. 6) due to the low acidity of former compared to latter one.

To probe the effect of added acid percentage on the rate of methylation reaction, we prepared ESI peptide solutions in $\mathrm{MeOH} / \mathrm{dH}_{2} \mathrm{O}(50: 50, \mathrm{v} / \mathrm{v})$ mixture containing $0.1 \%$ FA or AA and their full scan MS were recorded immediately after preparation. After 1, 3, 7, 14, and 30 day incubation periods, full scan MS were again acquired (The obtained mass spectra are illustrated in Fig. S10 and S11). As Fig. 6a displays, the extent of methylation was nearly same when $0.1 \%$ FA or AA was used for EGGFL-NH $\mathrm{N}_{2}$. On the contrary, the rate of D methylation was low when $0.1 \%$ AA was used instead of $0.1 \%$ FA (Fig. 6b).

Additionally, we have used EGGFL-OH and DGGFL-OH model pentapeptides where there were two potential methylation sites in each peptide. The obtained results demonstrated that the rate of mono- and di-methylation was significantly reduced when $0.1 \%$ acid was used instead of $1.0 \%$. Additionally, the extent of methylation was low for AA containing mixtures compared to the FA (Fig. $\mathrm{S} 12-15)$. It can be concluded that methylation of $\mathrm{E} / \mathrm{D}$ residue was significantly decreased if the peptide ESI solutions were prepared in $0.1 \%$ AA containing $\mathrm{MeOH} / \mathrm{dH}_{2} \mathrm{O}(50: 50, \mathrm{v} / \mathrm{v})$ mixture.

\subsection{Methylation of multiple acidic residues}

To investigate the extent of methylation of more than one acidic residue containing peptides, AAAAAAEE- $\mathrm{NH}_{2}$, AAAAAAEE-OH, and AAAAAADD-OH synthetic model hexapeptides have been used. The C-terminus amidated peptide has two potential methylation sites ( $7^{\text {th }}$ and $8^{\text {th }}$ acidic residues); whereas C-terminus free acid forms comprise of three potential methylation sites (two adjacent acidic residues positioned at $7^{\text {th }}$ and $8^{\text {th }}$ and C-terminus of peptide). The ESI peptide solutions were prepared freshly in a mixture of $\mathrm{MeOH} / \mathrm{dH}_{2} \mathrm{O} / \mathrm{FA}$ (50:50:1, v/v/v) and their full scan mass spectra were recorded in the range of $150-750 \mathrm{Da}$. The peptides were then allowed to incubate at $+37^{\circ} \mathrm{C}$ for thirty-days and their full scan MS again acquired.

For AAAAAAEE- $\mathrm{NH}_{2}$, in addition to the $[\mathrm{M}+\mathrm{H}]^{+}$ion at $m / z 702$, two isomeric mono-methylated peptide products (AAAAAAE $\mathrm{OMe}_{\mathrm{Me}} \mathrm{E}$ $\mathrm{NH}_{2}$ or AAAAAAEE $\left.\mathrm{OMe}-\mathrm{NH}_{2}\right)$ were observed at $m / z 716$, after thirty-day incubation at $+37^{\circ} \mathrm{C}$ (Fig. 7a). This ion was further selected and allowed to dissociate under low-energy CID conditions. The obtained MS/MS spectra consist of several sequence 

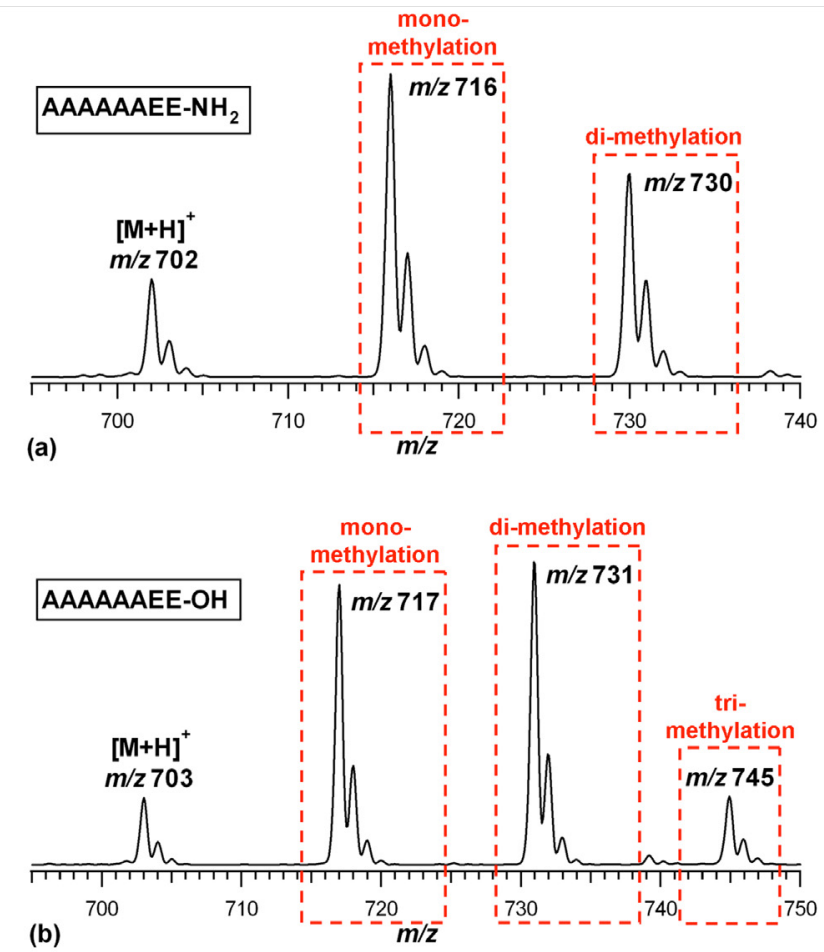

(b)

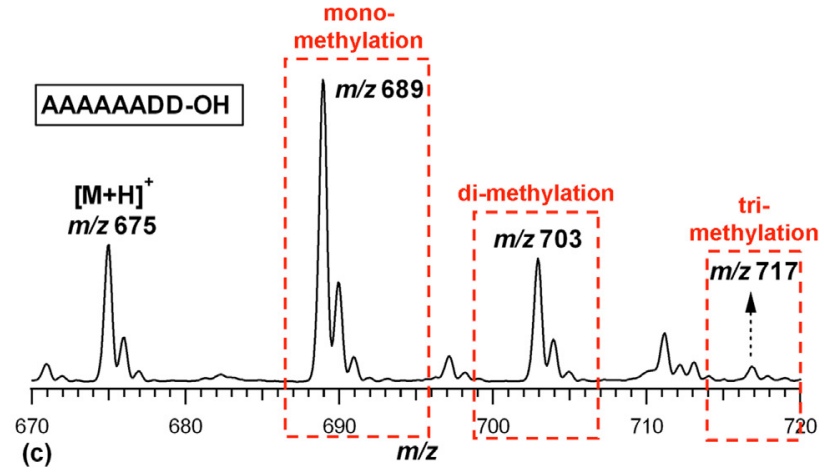

Fig. 7. The full scan MS of a) AAAAAAEE- $\mathrm{NH}_{2}$, b) AAAAAAEE-OH, and c) AAAAAADD$\mathrm{OH}$ incubated for thirty-day at $+37^{\circ} \mathrm{C}$. The ESI solutions were prepared in 50:50:1 (v/v/v) $\mathrm{MeOH} / \mathrm{dH}_{2} \mathrm{O} / \mathrm{FA}$.

specific ions, i.e. $b_{7}$ ions at $m / z 570$ and 556 can be accepted

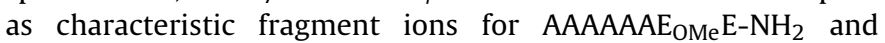
AAAAAAEE $\mathrm{OMe}-\mathrm{NH}_{2}$, respectively. Similarly, di-methylated peptide product (AAAAAAE $\mathrm{OMe}_{\mathrm{OMe}}-\mathrm{NH}_{2}$ ) ion was also detected at $m / z 730$ and its sequence was confirmed by subsequent MS/MS experiment. It is apparent that the rate of di-methylation is low compared to the rate of mono-methylation.

Additionally, the $[\mathrm{M}+\mathrm{H}]^{+}$ion of AAAAAAEE-OH is $\mathrm{m} / \mathrm{z} 703$ (see Fig. 7b). After thirty-day incubation at $+37^{\circ} \mathrm{C}$, mono-, di-, and tri-methylated peptide products were detected at $m / z 717$, 731 , and 745 , respectively. Briefly, three mono-methylated iso-

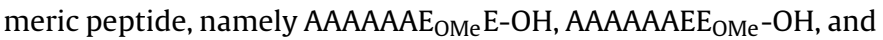
AAAAAAEE-OMe, were formed in solution. The formations of these three isomeric peptide derivatives have been verified via a careful interpretation of their corresponding low-energy CID-MS/MS spectra. On the other hand, three di-methylated peptide products (AAAAAAE $\mathrm{OMe}_{\mathrm{OMe}} \mathrm{E}_{\mathrm{OH}} \mathrm{OH}$ AAAAAE $\mathrm{OMe} \mathrm{E}-\mathrm{OMe}$, and AAAAAAEE $\mathrm{OMe}^{-}$ $\mathrm{OMe}$ ) were also formed in solution $(\mathrm{m} / \mathrm{z} 731)$ and their sequences were verified via MS/MS experiments. Lastly, tri-methylated peptide product (AAAAAAE $\mathrm{OMe}_{\mathrm{OMe}}-\mathrm{OMe}$ ) ion was detected at $m / z 745$ and the sequence was confirmed by monitoring its characteristic $b_{8}$ and $y_{2}$ ions at $m / z 713$ and 319, respectively in its MS/MS spectrum (spectrum not shown). It is obvious that the relative intensity of trimethylated peptide product ion was low compared to the monoand di-methylated ions.

Likewise, AAAAAADD-OH model hexapeptide was also methylated when its ESI solution was incubated at $+37^{\circ} \mathrm{C}$ for one month. As shown in Fig. 7c, the $[\mathrm{M}+\mathrm{H}]^{+}$ion is $m / z 675$ and mono-, di-, and tri-methylated peptide products were detected at $m / z 689,703$, and 717, respectively. The formation of these peptide products was further verified through MS/MS experiments along with assigning their sequence characteristic ions. The resulting full scan MS for AAAAAADD-OH showed that the rate of mono-methylation is high compare to the di- and tri-methylation. Di-methylation and tri-methylation on $\mathrm{E}$ residue is more obvious compared to the $\mathrm{D}$ residue where the rate of $\mathrm{D}$ mono-methylation is higher compared to the E mono-methylation.

\subsection{Effects of different organic solvent on the esterification reaction}

To investigate the effect of different organic solvents on the esterification reaction, the methanol was substituted with ethanol $(\mathrm{EtOH})$ or isopropanol $(\mathrm{iPrOH})$ in sample preparation steps. These solvents were used to compare the effects of primary $(\mathrm{MeOH}$ or EtOH) and secondary alcohol $(i \mathrm{PrOH})$ on the esterification reaction of E/D residues as well as C-terminus of peptide. For that purposes, EGGFL-NH $\mathrm{N}_{2}$, DGGFL-NH $\mathrm{N}_{2}, \mathrm{EGGFL-OH}$, and DGGFL-OH synthetic model pentapeptides have been used. For each peptide sample, a final concentration of $100 \mathrm{pmol} \mu \mathrm{L}^{-1}$ was freshly prepared in a mixture of EtOH/ $\mathrm{dH}_{2} \mathrm{O} / \mathrm{FA}$ or $i \mathrm{PrOH} / \mathrm{dH}_{2} \mathrm{O} / \mathrm{FA}$ (50:50:1, $\mathrm{v} / \mathrm{v} / \mathrm{v}$ ) separately and their full scan MS were acquired immediately. For the best representation of the esterification reaction, the incubation temperature and added acid were selected as $+37^{\circ} \mathrm{C}$ and $1 \%$ FA, respectively. Then, each solution was allowed to incubate at $+37^{\circ} \mathrm{C}$ for $1,3,7,14$, and 30 days. After specified time periods, the full scan MS were again recorded.

For ethylation reaction, the comparison of full scan MS obtained from freshly prepared and thirty-day incubated EGGFL- $\mathrm{NH}_{2}$ and DGGFL- $\mathrm{NH}_{2}$ peptide solutions were shown in Fig. 8a and $\mathrm{b}$ (The obtained full scan MS of EGGFL-NH $\mathrm{N}_{2}$ and DGGFL- $\mathrm{NH}_{2}$ for $1,3,7$, 14 , and 30 days are given in Fig. S16). For EGGFL-NH $\mathrm{N}_{2}$, the $[\mathrm{M}+\mathrm{H}]^{+}$ ion has a mass of $m / z 521$ with minor sodium adduct, $[\mathrm{M}+\mathrm{Na}]^{+}$, at $m / z$ 543. It can be noticed that the $m / z 549$ ion was observed for incubated peptide sample which has a mass difference of +28 Da with respect to the $[\mathrm{M}+\mathrm{H}]^{+}$ion (see Fig. 8a). This mass shift can be attributed to the ethylation of $E$ residue. To support this assumption, $m / z 549$ ion was further selected and fragmented via low-energy CID. The resultant MS/MS spectrum showed that $b_{3}$, $b_{4}$, and $b_{5}$ ions were shifted by +28 Da compared to the same ions for unmodified peptide (spectrum not shown). Therefore, this solid evidence proved that the side chain of $E$ residue was ethylated. Similarly, $m / z 535$ was appeared in the full scan MS of DGGFL-NH $\mathrm{N}_{2}$ for thirty-day incubated solution where it was originally absent for freshly prepared one (see Fig. 8b). Detailed MS/MS experiment showed that $\mathrm{D}$ residue was also ethylated when the peptide solution was prepared in $\mathrm{EtOH} / \mathrm{dH}_{2} \mathrm{O} / \mathrm{FA}(50: 50: 1, \mathrm{v} / \mathrm{v} / \mathrm{v})$. The rate of $\mathrm{D}$ ethylation is higher compared to the E ethylation. The obtained results on ethylation were in good agreement with the previous studies [14,16,27].

Additionally, EGGFL-OH and DGGFL-OH model pentapeptides were also analyzed for ethylation reaction. For these peptides, we expected to observe both mono- and di-ethylated peptide products. As Fig. S17 illustrates, mono-ethylated and di-ethylated peptide products were appeared with a mass increase of $+28 \mathrm{Da}$ and $+56 \mathrm{Da}$, respectively, in the full scan MS of EGGFL-OH and DGGFL-OH. Briefly, mono-ethylated (E $\mathrm{EEt}_{\mathrm{OE}} \mathrm{GGFL-OH}$ or EGGFL-OEt) 

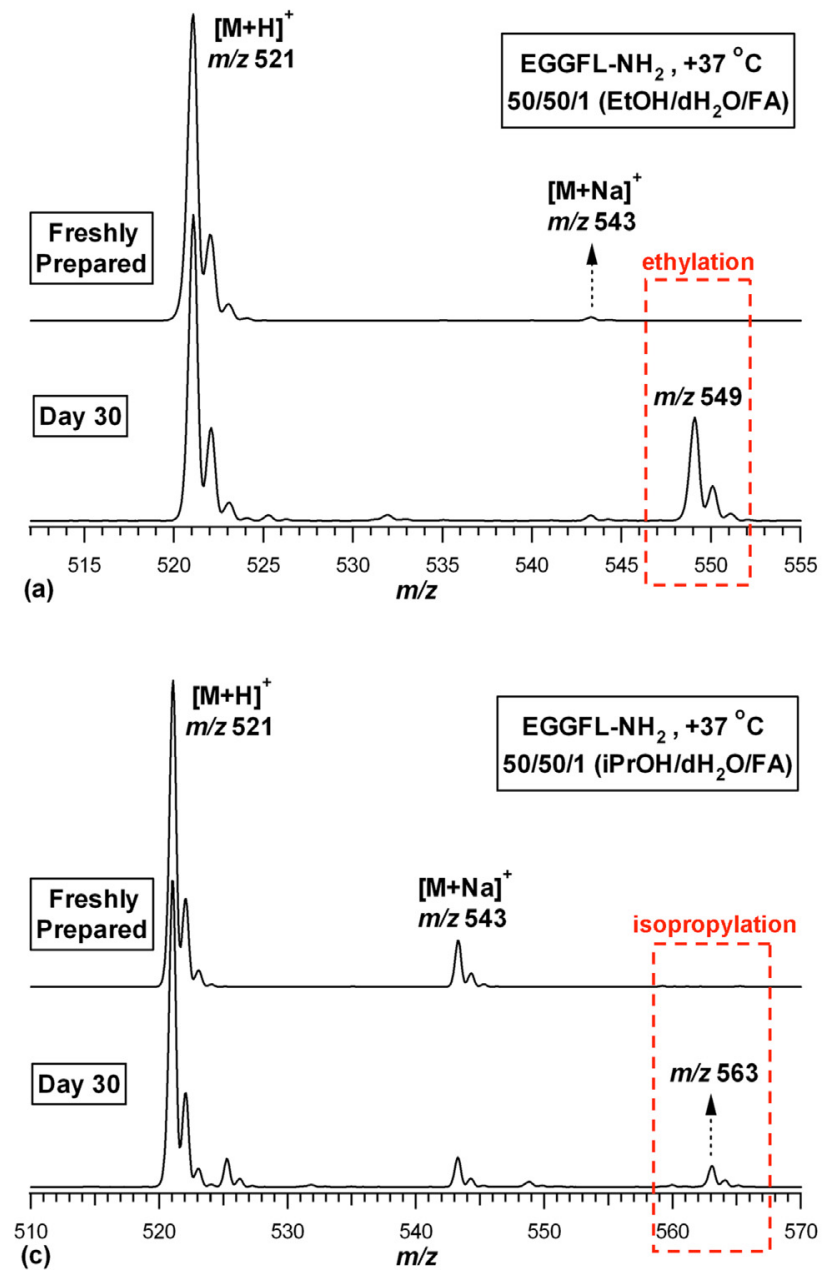
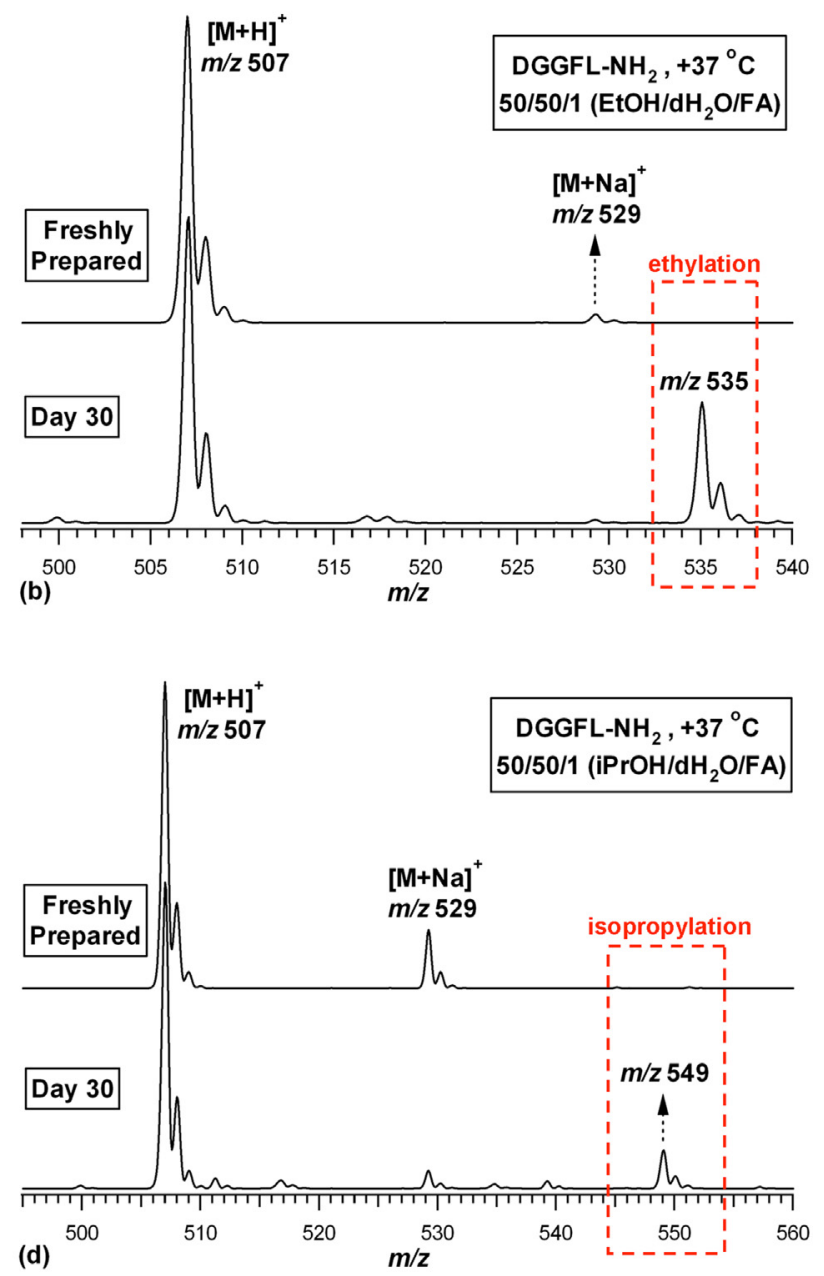

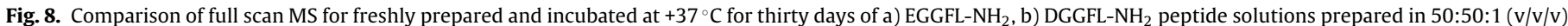
EtOH/dH $\mathrm{dH}_{2} \mathrm{O} / \mathrm{FA}$, and c) EGGFL-NH $\mathrm{N}_{2}$, d) DGGFL- $\mathrm{NH}_{2}$ peptide solutions prepared in 50:50:1 (v/v/v) $i$ PrOH/dH $\mathrm{H}_{2} \mathrm{O} / \mathrm{FA}$.

and di-ethylated ( $\mathrm{E}_{\mathrm{OEt}} \mathrm{GGFL}-\mathrm{OEt}$ ) peptide products were observed at $\mathrm{m} / \mathrm{z} 550$ and 578, respectively. Similarly, for DGGFL-OH, mono-methylated ( $\mathrm{D}_{\mathrm{OEt}}$ GGFL-OH or DGGFL-OEt) and di-ethylated ( $\mathrm{D}_{\mathrm{OEt}} \mathrm{GGFL}-\mathrm{OEt}$ ) peptide products were detected at $\mathrm{m} / \mathrm{z} 536$ and 564 , respectively. The formation of each of these peptide products were identified via MS/MS experiments followed by monitoring their sequence characteristic ions. It is interesting to note that the degree of mono-ethylation on $\mathrm{D}$ residue is greater than monoethylation on E residue. However, the extent of di-ethylation was nearly same after thirty-day incubation. Moreover, as expected, the relative intensities of di-ethylated peptide products were low compared to the mono-ethylated peptide products for both peptides.

Furthermore, to explore the effect of secondary alcohol on the esterification reaction, four ESI peptide solutions were freshly prepared in a mixture of $i \mathrm{PrOH} / \mathrm{dH}_{2} \mathrm{O}(50: 50, \mathrm{v} / \mathrm{v})$ containing $1 \%$ of

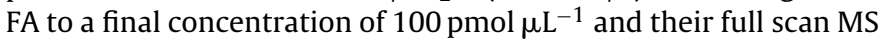
were immediately acquired in the mass range of $m / z 150-620$.After $1,3,7,14$, and 30 days incubation period, the full scan MS were again recorded and compared, as Fig. 8c illustrates (The obtained full scan MS of EGGFL-NH $\mathrm{N}_{2}$ and DGGFL-NH 2 for $1,3,7,14$, and 30 days are given in Fig. S18). For EGGFL- $\mathrm{NH}_{2}$, the $[\mathrm{M}+\mathrm{H}]^{+}$ion is $\mathrm{m} / z 521$ along with its sodium adduct at $\mathrm{m} / z$ 543. It can be noticed that $m / z 563$ was appeared in the full scan MS which corresponds to a mass shift of $+42 \mathrm{Da}$. Similarly, the $[\mathrm{M}+\mathrm{H}]^{+}$ion of DGGFL- $\mathrm{NH}_{2}$ is $\mathrm{m} / z 507$ and $\mathrm{m} / \mathrm{z} 549$ was detected with a mass increase of $+42 \mathrm{Da}$ (see Fig. 8d). In line with methylation and ethylation reactions, we assumed that the side chains of $\mathrm{E} / \mathrm{D}$ residues were isopropylated when their peptide solutions were prepared in $i \mathrm{PrOH} / \mathrm{dH}_{2} \mathrm{O} / \mathrm{FA}$ (50:50:1, v/v/v) after storage at $+37^{\circ} \mathrm{C}$ over a month. Further MS/MS experiments have confirmed that $b_{3}, b_{4}$, and $b_{5}$ ion series were shifted by $+42 \mathrm{Da}$ with respect to original peptide sequence. As Fig. S18 illustrates, the isopropylation was began after seven-day incubation both for E and D containing model pentapeptides. However, the rate of isopropylation was markedly low compared to the ethylation and methylation. This aspect can be explained by steric hindrance behavior of $\mathrm{iPrOH}$ compare to the $\mathrm{MeOH}$ and $\mathrm{EtOH}$. Hence, the rate of esterification of the side chains of E/D residues as well as C-terminus of peptide became slower when $i \mathrm{PrOH}$ was used. Additionally, our results differ from Haebel et al. [14] report in terms of isopropylation. The authors previously used $i \mathrm{PrOH}$ as an organic solvent to test esterification of E/D residues. However, they did not observe any isopropylated peptide product.

Moreover, EGGFL-OH and DGGFL-OH model pentapeptides were also utilized for examining mono- and di-isopropylation. The peptide samples were prepared freshly in $i \mathrm{PrOH} / \mathrm{dH}_{2} \mathrm{O} / \mathrm{FA}$ (50:50:1, $\mathrm{v} / \mathrm{v} / \mathrm{v}$ ) mixture and full scan MS were recorded immediately. Then, the samples were incubated at $+37^{\circ} \mathrm{C}$ over $1,3,7,14$, and 30 days and the full scan MS were again recorded after each time period. The comparison of full scan MS generated from incubated peptide samples over different time intervals were shown in Fig. S19. The $m / z 564$ and 550 were detected for EGGFL-OH and DGGFL-OH solutions, respectively, after 7-day incubation. These ions corre- 
spond to the mono-isopropylation; either on the side chains of E/D residues or on the C-terminus of peptide. Further MS/MS experiments have revealed that both two mono-isopropylated peptide products were formed during storage. However, it is interesting to note that di-isopropylated peptide products $(\mathrm{m} / z 606$ for EGGFL-OH and $m / z 593$ for DGGFL-OH) were absent for thirty-day incubated peptide samples. Our further experiments showed that formation of di-isopropylated peptide products requires at least three-month incubation at $+37^{\circ} \mathrm{C}$.

\section{Conclusion}

This work presents a detailed investigation of $O$-methylation on the side chains of E/D residue and C-terminus of peptide as a function of different incubation temperatures $\left(-20^{\circ} \mathrm{C},+4^{\circ} \mathrm{C},+22^{\circ} \mathrm{C}\right.$, $+37^{\circ} \mathrm{C}$, or $\left.+50^{\circ} \mathrm{C}\right)$, storage times $(1,3,7,14$, and 30 days $)$, added acid type and its percentages ( $0.1-1 \%$ FA or $A A)$ by using synthetic model peptide series. The methylation was confirmed by +14 Da mass shift in peptide $b$ and/or $y$ ion series as well as an exclusive loss of methanol ( $-32 \mathrm{Da}$ ) from $b$ and/or $a$ ions upon CID.

The obtained results have revealed that methylation of the side chains of $E / D$ residues and C-terminus is temperature dependent process and the heating an acidified ESI solution greatly enhances the rate of reaction. On the other hand, no methylated peptide products were observed if peptide ESI solutions were stored $-20^{\circ} \mathrm{C}$ for a month. The results have also demonstrated that long incubation times remarkably favor the formation of methylated products.

On the other hand, the extent of methylation was found to decrease when $1.0 \%$ AA used instead of 1.0\% FA for all tested peptides and this aspect can be explained low acid strength of former with respect to latter one. Additionally, the usage of $0.1 \%$ FA or AA significantly diminishes the formation of methylated products. These results collectively suggested that peptide solution storage conditions can effect methylation reaction. To avoid this unwanted modification, the peptide ESI solutions must be acidified with $0.1 \%$ AA just prior to use through MS analysis and should be stored at $-20^{\circ} \mathrm{C}$ for further use.

The extent of multiple methylations was also studied by using two E/D containing model peptides. The resulting mass spectra showed that mono-and di-methylated peptide products were observed for AAAAAAEE- $\mathrm{NH}_{2}$ peptide. In addition, we detected mono-, di-, and tri-methylated peptide products of AAAAAAEE$\mathrm{OH}$ and AAAAAADD-OH. However, the rate of tri-methylation is low compared to the mono- and di-methylation. Finally, $\mathrm{MeOH}$ was replaced with EtOH or $i \mathrm{PrOH}$ to examine the effect of organic solvent type on the esterification reactions. The obtained results showed that the ethylation ( $+28 \mathrm{Da}$ mass shift) is more obvious than the isopropylation (+42 Da mass shift). This behavior can be explained by bulky nature $i \mathrm{PrOH}$ compare to the EtOH which directly influences the kinetics of esterification reaction.

In conclusion, preparing ESI solutions of E/D residue containing synthetic peptides in an acidified $\mathrm{MeOH} / \mathrm{dH}_{2} \mathrm{O}$ mixture can induce generation of methylated peptide products. This artificial chemical modification during sample preparation causes misidentification of endogenous methylation of peptides/proteins; hence a special care must be taken while evaluating MS data through search algorithms. Taken together, on the other hand, the aforementioned procedure provides good yields of methylated peptide products for further MS/MS studies, especially while studying synthetic model peptides.

\section{Acknowledgements}

The authors gratefully acknowledge the State Planning Organization (DPT) of Turkey for the funding of the Biological Mass Spectrometry and Proteomics Facility located at Izmir Institute of Technology. A.E.A. is also grateful to Scientific and Technological Research Council of Turkey TUBITAK, for post-doctoral support under project $113 \mathrm{Z172}$ (COST 1306).

\section{Appendix A. Supplementary data}

Supplementary data associated with this article can be found, in the online version, at http://dx.doi.org/10.1016/j.jchromb.2016. 12.043 .

\section{References}

[1] J.B. Fenn, M. Mann, C.K. Meng, S.F. Wong, C.M. Whitehouse, Electrospray ionization mass spectrometry of large molecules, Science 246 (1989) 64-71.

[2] J.R. Yates III, Mass spectrometry and the age of the proteome, J. Mass Spectrom. 33 (1998) 1-19.

[3] M. Mann, O.N. Jensen, Proteomic analysis of post-translational modifications, Nat. Biotechnol. 21 (3) (2003) 255-261.

[4] E.S. Witze, W.M. Old, K.A. Resing, N.G. Ahn, Mapping protein post-translational modifications with mass spectrometry, Nat. Methods 4 (10) (2007) 798-806.

[5] B.D. Strahl, C.D. Allis, The language of covalent histone modifications, Nature 403 (6765) (2000) 41-45.

[6] M.T. Bedford, S. Richard, Arginine methylation: review an emerging regulator of protein function, Mol. Cell 18 (2005) 263-272.

[7] A.N. Lake, M.T. Bedford, Protein methylation and DNA repair, Mutat. Res. 618 $(1 / 2)(2007) 91-101$

[8] W.K. Paik, D.C. Paik, S. Kim, Historical review: the field of protein methylation, Trends Biochem. Sci. 32 (2007) 146-152.

[9] M.T. Bedford, S.G. Clarke, Protein arginine methylation in mammals: who what, and why, Mol. Cell 33 (2009) 1-13.

[10] M.T. Bedford, Arginine methylation at a glance, J. Cell Sci. 120 (24) (2007) 4243-4246.

[11] C.T. Walsh, S. Garneau-Tsodikova, G.J. Gatto Jr., Protein posttranslational modifications: the chemistry of proteome diversifications, Angew. Chem. Int. Ed. Engl. 44 (2005) 7342-7372.

[12] R. Sprung, Y. Chen, K. Zhang, D. Cheng, T. Zhang, J. Peng, Y. Zhao, Identification and validation of eukaryotic aspartate and glutamate methylation in proteins, J. Proteome Res. 7 (3) (2008) 1001-1006.

[13] K. Wang, Y. Zhou, H. Liu, K. Cheng, J. Mao, F. Wang, W. Liu, M. Ye, Z.K. Zhao, H. Zou, Proteomic analysis of protein methylation in the yeast Saccharomyces cerevisiae, J. Proteomics 114 (2015) 226-233.

[14] S. Haebel, T. Albrecht, K. Sparbier, P. Walden, R. Korner, M. Steup, Electrophoresis-related protein modification: alkylation of carboxy residues revealed by mass spectrometry, Electrophoresis 19 (1998) 679-686.

[15] D. Sumpton, W. Bienvenut, Coomassie stains: are they really mass spectrometry compatible? Rapid Commun. Mass Spectrom. 23 (2009) $1525-1529$.

[16] G. Chen, H. Liu, X. Wang, Z. Li, In vitro methylation by methanol: proteomic screening and prevalence investigation, Anal. Chim. Acta 661 (2010) 67-75.

[17] R. Nakao, K. Oka, T. Fukumoto, A simple method for the esterification of carboxylic acids using chlorosilanes, Bull. Chem. Soc. Jpn. 54 (1981) 1267-1268.

[18] A.S.-Y. Lee, H.-C. Yang, F.-Y. Su, An unprecedented and highly chemoselective esterification method, Tetrahedron Lett. 42 (2001) 301-303.

[19] M.-Y. Chen, A.S.-Y. Lee, A simple and efficient esterification method, J. Chin. Chem. Soc. 50 (2003) 103-108.

[20] S.Y. Jung, Y. Li, Y. Wang, Y. Chen, Y. Zhao, J. Qin, Complications in the assignment of 14 and 28 Da mass shift detected by mass spectrometry as in vivo methylation from endogenous proteins, Anal. Chem. 80 (2008) 1721-1729.

[21] A.E. Atik, T. Yalcin, A systematic study of acidic peptides for $b$-type sequence scrambling, J. Am. Soc. Mass Spectrom. 22 (2011) 38-48.

[22] A.E. Atik, T. Yalcin, Protonated dipeptide losses from $b_{5}$ and $b_{4}$ ions of side chain hydroxyl group containing pentapeptides, J. Am. Soc. Mass Spectrom. 24 (2013) 1543-1554.

[23] N.N. Dookeran, T. Yalcin, A.G. Harrison, Fragmentation reactions of protonated $\alpha$-amino acids, J. Mass Spectrom. 31 (1996) 500-508.

[24] A.G. Harrison, Ion chemistry of protonated glutamic acid derivatives, Int. J. Mass Spectrom. 210/211 (2001) 361-370.

[25] D. Chelius, K. Jing, A. Lueras, D.S. Rehder, T.M. Dillon, A. Vizel, R.S. Rajan, T. Li, M.J. Treuheit, P.V. Bondarenko, Formation of pyroglutamic acid from $\mathrm{N}$-terminal glutamic acid in immunoglobulin gamma antibodies, Anal. Chem. 78 (2006) 2370-2376.

[26] W.M. Haynes, CRC Handbook of Chemistry and Physics, 95th ed., CRC Press, 2014.

[27] G. Xing, J. Zhang, Y. Chen, Y. Zhao, Identification of four novel types of in vitro protein modifications, J. Proteome Res. 7 (10) (2008) 4603-4608. 